\title{
Editorial: Innovation and Creativity in a Time of Crisis
}

\author{
Maggie Bartlett ${ }^{\mathrm{a}},{ }^{*}$ Stella Howden ${ }^{\mathrm{a}}$, Alison Jones ${ }^{\mathrm{bc}}$, Linda Martindale ${ }^{\mathrm{a}}$ \\ a: University of Dundee, United Kingdom; b: Kingston University, United Kingdom; \\ c: St George's University of London, United Kingdom
}

\begin{abstract}
The sudden emergence of the COVID-19 pandemic in March 2020 caused rapid change across the world, not least in the field of practice-based education for health and social care students. The imperative of supporting students to complete their programmes to ensure that they could enter the workforce on time led to a surge of creativity and innovation underpinned by knowledge, skills, experience, and plain hard work.
\end{abstract}

In this, the first of two parts of this special issue, we hope to harness some of the learning and experience gained during this time of disruption to inform future developments. We also want to celebrate the work of programme teams in designing changes that brought some order and optimism to the early sense of chaos and worry.

This issue includes eight articles, five of which are evaluations of changes introduced as a response to the pandemic, and three of which are reflective pieces. A range of disciplines are represented, including Allied Health Professionals (AHPs), Physiotherapy, Speech and Language Therapy, Occupational Therapy, and Medicine, with author representation from Australia, Ireland, South Africa and the United Kingdom.

Common to all the articles we have included, is a sense of the energy, commitment, and courage of educators. There is a clear demonstration of an ability to focus on what is of critical importance to students, programmes and the workforce, and to work collaboratively with others to address the challenges faced by all.

Two articles give examples of strong national collaboration leading to effective change. St. JohnMatthews and colleagues (2021) in the United Kingdom, describe the use of a digital methodology (cloud sourcing) to gather and explore insights from 1,000 participants (educators, students, and clinicians) across the four United Kingdom nations. This led to the development of national resources such as webinars and a repository of learning resources for AHPs, and significant funding for placements. O'Grady and colleagues (2021) describe how building on existing relationships enabled a move from a situation in which the four Irish universities sought clinical placements independently from each other to a more sustainable model where they worked together to make the best use of capacity across the nation.

*Corresponding Author: Dr Stella Howden, Reader, School of Medicine, Dundee University, Ninewells Hospital \& Medical School, Dundee, DD1 9SY United Kingdom

Email: s.howden@dundee.ac.uk

Journal URL: https://publications.coventry.ac.uk/index.php/pblh

Bartlett, M., Howden, S., Jones, A., \& Martindale, L. (2021). Editorial: Innovation and creativity in a time of crisis. International Journal of Practice-based Learning in Health and Social Care, 9(1), ii-iv. DOI 10.18552/ijpblhsc.v9i1.758. BY NC ND (C) 2021 Maggie Bartlett, Stella Howden, Alison Jones, and Linda Martindale. This Open Access
article is distributed under the terms of the Creative Commons Attribution Attribution-Non-Commercial No Derivatives 4.0 International License (https://creativecommons.org/licenses/by-nc-nd/4.0/ ), which permits unrestricted non-commercial use, distribution, and reproduction in any medium, provided the original work is properly cited and is unaltered. 
Many of the articles describe and evaluate changes made to placements to address the suspension of faceto-face clinical services and practice-based teaching. In some instances, teaching sessions were moved online, requiring rapid adaptation and skill development from educators and students.

Kamper and colleagues (2021) in Australia, reflect on the rapid development of pre-existing telehealth services as effective locations for practice-based learning in Speech and Language Therapy. Lyons and colleagues (2021) evaluate a telehealth service that was established in Ireland as a response to the pandemic to deliver Speech and Language Therapy and included placements for students.

Two articles from the United Kingdom (Marchant, 2021; Taylor \& Salmon, 2021), evaluate new online placements for Occupational Therapy and AHP students respectively. Both groups report success for students' learning and management of placement capacity, although Marchant (2021) highlights negative impacts on students' sense of belonging to a team.

Lawton and colleagues (2021) evaluate a move to project-based placements for Physiotherapy students in Australia which enabled different but varied learning that mirrored real world practice. May et al. (2021), also from Australia, describe and evaluate a change to a final year rotation for medical students. This involved a move from a rotation of short clinical attachments to a more embedded placement with a competency-based portfolio, with positive impacts for both students and supervisors.

There is no doubt that the availability of digital technologies has been central to the responses of universities across the world. It is notable that, although all the articles we have included identify some challenges in moving teaching online, only one identifies the issue of digital poverty; Gurayah (2021) reflects on the challenges of establishing online teaching in South Africa where some students may not have had their own devices or access to sufficient data but identifies the 'flexibility and resilience' that helped them to adapt to new ways of learning.

Although the changes and developments that are described in this issue were forced on institutions by the pandemic and were necessarily put in place very quickly, it is likely that some will endure once the crisis is resolved. For some, the changes needed were imposed at speed by the situation and without any prior intention. For others, the pandemic led to a removal or amelioration of perceived barriers to change thereby facilitating or accelerating the implementation of pre-existing aspirations such as the collaborative approach to managing placement capacity or a move to more online teaching. For Taylor \& Salmon (2021, p. 8), the "driver of the pandemic enabled re-thinking of practice learning" and they conclude that the changes they made may be "a legitimate and sustainable model of placement delivery'

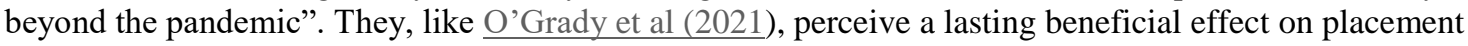
capacity. May et al. (2021) comment that the changes they had to make to the penultimate year of their programme have led to a revision of the penultimate year of the curriculum with an "expectation of gains in students' satisfaction and in employability.

The experiences and adaptations described by our colleagues who have contributed to this special issue reflect the idea that the further organisations are from certainty and agreement, the more innovation takes place to solve problems and avoid chaos (Stacey \& Mowles, 2016). The pandemic suddenly removed the option of continuing agreed and accepted educational practices established over many years, and we have experienced ways of doing things differently in an accelerated manner. The task now is to build on these innovations where they have been successful.

\section{ORCID}

Maggie Bartlett

Stella Howden

Linda Martindale https://orcid.org/0000-0001-9200-7645

https://orcid.org/0000-0002-6460-3869

https://orcid.org/0000-0002-4526-382X 


\section{References}

Gurayah, T. (2021). Practice learning for occupational therapy in a time of the global COVID-19 pandemic. International Journal of Practice-Based Learning in Health and Social Care, 9(2), 82-84. https://doi.org/10.18552/ijpblhsc.v9i2.728

Kamper, S.J., Dario, A. B., Waibel, M., O’Connor, D., \& Bourne, E. (2021). Co-designing innovative practice-based education for speech pathology students. International Journal of Practice-Based Learning in Health and Social Care, 9(2), 74-77. https://doi.org/10.18552/ijpblhsc.v9i2.746

Lawton, V., Vaughan, R., Jones, T. M., \& Pacey, V. (2021). Rising to the challenge of COVID-19: Pivoting to online and project-based physiotherapy student placements in contemporary professional settings. International Journal of Practice-Based Learning in Health and Social Care, 9(2), 21-38. https://doi.org/10.18552/ijpblhsc.v9i2.747

Lyons, R., Loftus, L., Rodden, M., Ward Lynch, S., Gaffney, S., \& McAndrew, B. (2021). Establishment of an innovative telehealth speech and language therapy placement as a rapid response to COVID-19: Sharing the learning. International Journal of Practice-Based Learning in Health and Social Care, 9(2), 11-20. https://doi.org/10.18552/ijpblhsc.v9i2.738

Marchant, J. (2021). Understanding the Allied Health Professions student experience of practice placements during the first wave of the coronavirus pandemic. International Journal of PracticeBased Learning in Health and Social Care, 9(2), 39-48. https://doi.org/10.18552/ijpblhsc.v9i2.741

May, J., Grotowski, M., Walker, T., \& Kelly, B. (2021). Rapid implementation of a novel embedded senior medical student program as a response to the educational challenges of COVID-19. International Journal of Practice-Based Learning in Health and Social Care, 9(2), 63-73. https://doi.org/10.18552/ijpblhsc.v9i2.736

O’Grady, K., Loftus, L., Kiely, F., \& Quigley, D. (2021). Reflections on a collaborative, cross-university national call for speech and language therapy practice placements during the COVID-19 pandemic. International Journal of Practice-Based Learning in Health and Social Care, 9(2), 78-81. https://doi.org/10.18552/ijpblhsc.v9i2.721

Stacey, R. D., \& Mowles, C. (2016). Strategic management and organisational dynamics: The challenge of complexity to ways of thinking about organisations (7th ed.). Pearson.

St. John-Matthews, J., Hobbs, C., Chapman, P., Marsden, D., Allarton, R., Booth, A., Martin, F., Woodley, J., \& Harden, B. (2021). Ensuring an essential supply of Allied Health Professions (AHP) placements: Using crowdsourcing to develop a national call to action. International Journal of Practice-Based Learning in Health and Social Care, 9(2), 49-62. https://doi.org/10.18552/ijpblhsc.v9i2.732

Taylor, L., \& Salmon, G. (2021). Enhancing peer learning through online placements for Health and Social Care Professions. International Journal of Practice-Based Learning in Health and Social Care, 9(2), 1-10. https://doi.org/10.18552/ijpblhsc.v9i2.723 